\title{
Voldemar Sumberg ja Eesti Tervishoiu Muuseumi rahvameditsiinikogu ${ }^{1}$
}

\author{
Ave Goršič \\ Eesti Kirjandusmuuseumi Eesti Rahvaluule Arhiivi teadur \\ avegorsic@folklore.ee
}

\begin{abstract}
Teesid: 1922. aastal asutatud Eesti Tervishoiu Muuseumi (praeguse samanimelise muuseumi eelkäija) tegevuse üheks põhimõtteks nimetati muuseumi dokumentides ja artiklites arstimistarkuse kogumist ja igakülgset läbitöötamist. Sellega taheti tähelepanu juhtida rahva seas kasutusel olevatele meditsiinilistele väärvõtetele ja teha üldrahvalikku kasvatustööd tervishoiu alal. Muuseumile tegid kogumisalast kaastööd mitmed kirjasaatjad, lisaks saadeti stipendiaatidena koguma vanema kursuse arstiteaduse üliõpilasi. 1935. aastaks oli talletatud hulgaliselt rahvameditsiinilisi teateid ning mitmesuguseid rahvapäraseid arstiriistu, mis olid välja pandud ka muuseumi püsinäitusel.

Käesolev artikkel avab Voldemar Sumbergi kui muuseumi juhataja tegevust rahvameditsiini kogumise edendamisel 1920. aastate algupoolel, Eesti Tervishoiu Muuseumi rahvameditsiini kogumistöö tulemusi ja kogu tänaseni säilinud osa.

Märksõnad: Eesti Tervishoiu Muuseum, kogumine, küsitluskavad, meditsiiniajalugu, rahvameditsiin, Voldemar Sumberg
\end{abstract}

Eesti rahvameditsiini oli 20. sajandi alguskümnenditeni kogutud sporaadiliselt ning peamiselt ilmus temaatilisi kirjutisi arstide sulest, autoriteks nt Johann Wilhelm Ludwig Luce (1750-1842), Karl Ernst von Baer (1792-1876), Friedrich Robert Faehlmann (1798-1850), Friedrich Reinhold Kreutzwald (1803-1882), Peeter Hellat (1857-1912). Mitmeid meditsiinialaseid, sh rahvameditsiini käsitlevaid artikleid avaldati ka ajakirjas Eesti Kirjandus. Rahvameditsiini laialdasemale kogumisele aitas paljuski kaasa Jakob Hurda (1839-1907) laiapõhjaline rahvaluulekogumise ülekutse 1888. aastast. Korrapärane rahvameditsiini materjalide kogumine ja uurimine sai alguse Eesti Rahva Muuseumi (ERM) alla kuuluva Eesti Rahvaluule Arhiivi (ERA) asutamisega 1927. aastal.

Artikli keskmeks olev Eesti Tervishoiu Muuseum (ETM) asutati Tartus 22. novembril 1922. aastal ning avati rahvale 21. detsembril 1924. Tervishoiumuuseumid Helsingis, Dresdenis, Berliinis, Amsterdamis ja Pariisis olid seejuures Eesti muuseumi loomisel eeskujuks. Arhiividokumentidest ei selgu, 
kas välismaistes muuseumides oli rahvameditsiinile pühendatud väljapanekuid, kuid neilt lähetustelt naasnud Voldemar Sumbergi eestvõttel keskenduti ETMi ülesehitamisel pigem uutele teadmistele ja õppematerjalidele. Viimast, õppeülesannet, pidi täitma ka rahvameditsiinikogu.

ETMi põhimõtete seas nimetati seega erinevates artiklites ja muuseumi dokumentides muuhulgas vanavara arstimistarkuse kogumist ja igakülgset läbitöötamist, teadmiste päästmist kogumise kaudu ning tähelepanu juhtimist rahva seas kasutusel olevatele väärvõtetele. Muuseumile tegid kaastööd mitmed kirjasaatjad, lisaks saatis ETM stipendiaatidena koguma vanema kursuse arstiteaduse üliõpilasi. 1935. aastal nentis V. Sumberg muuseumi juubeliülevaates, et kokku on kogutud 16563 rida rahvameditsiini teateid ning mitmesuguseid rahvapäraseid arstiriistu (Sumberg 1935: 60-61). Nimetatud kogumiste tulemused on valdavalt jäänud uurimata. Suur osa materjalidest on ajaloosündmuste tõttu kas hävitatud või hävinenud. Praeguseks on nimetatud kogumisaktsioonide tulemuste ja muuseumi loomise taustu avatud inglisekeelsetes artiklites (Tupits 2010; Goršič 2016), eestikeelne käsitlus kogutust on jäänud lugejateni toomata.

Käesolev artikkel tutvustab Voldemar Sumbergi tegevust rahvameditsiini korjamise edendamisel 1920. aastate algupoolel ning Tervishoiu Muuseumi rahvameditsiini kogu loomisel. Artikkel toetub mainitud aktsioonidega seotud taustmaterjalidele, mis asuvad Rahvusarhiivis (st endises Eesti Riigiarhiivis ja endises Eesti Ajalooarhiivis) ning tänaseni säilinud osale rahvameditsiinikogust, avades ka 1920. aastatel koostatud Eesti Üliõpilaste Seltsi-Eesti Rahva Muuseumi ja ETMi küsitluskavade sisu.

\section{Eesti Üliõpilaste Seltsi ja Eesti Rahva Muuseumi küsitluskava}

Voldemar Kristjan Sumberg ((28. märts) 9. aprill 1893 - 13. veebruar 1965) oli eesti arst, Eesti Tervishoiu Muuseumi asjaajaja ja juhataja. 1922. aastal töötas Sumberg Tartus Ülikooli Tervishoiu Instituudis sanitaar-topograafina ning vabatahtliku assistendina. Samal aastal määrati ta Tervishoiu Muuseumi asjaajajaks, 1923. aastal valiti Tervishoiu Instituudi nooremassistendiks ning vabastati sellest ametist enda palvel 1. jaanuaril 1925. Sumberg õppis ülikoolis arstiteadust aastatel 1915-1918 ja 1920-1922 ning tegi farmakoloogias järeleksami 1925. aastal. Vabadussõja ajal tegutses ta muuhulgas sõjaväes velskrina. Sumberg oli ka EÜSi liige, ajakirja Tervis toimetaja aastatel 1928-1944 (RA, EAA.2100.2.1153: 1-6p, 22, 30-31p) ja mitmete tervishoiualaste käsiraamatute kaasautor. Muuhulgas saatis ta M. J. Eisenile 1929. aastal naljandeid kirikutegelaste kohta (E 63614, E 63698-63699, E 63700-63702). 


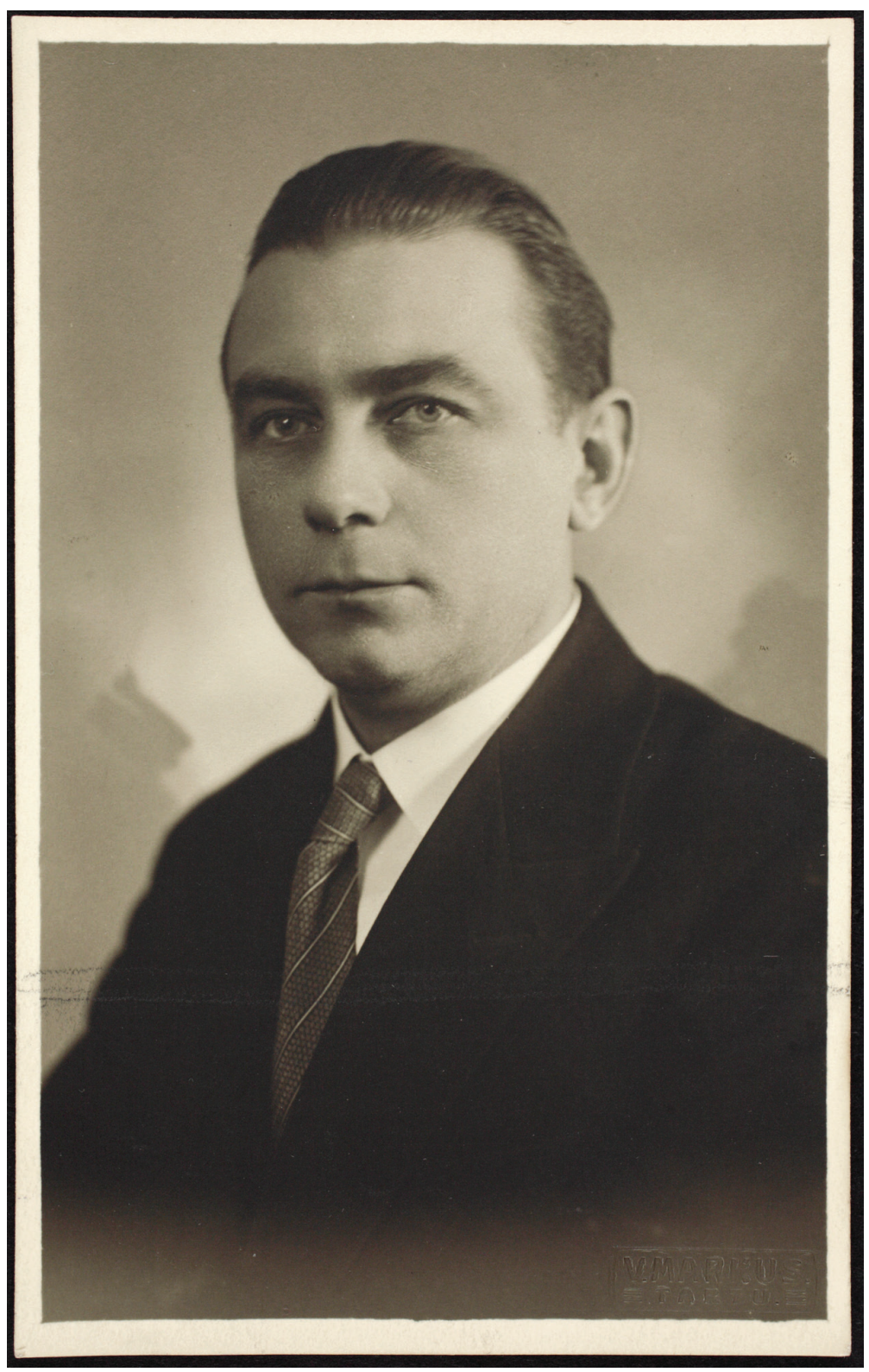

Pilt 1. Voldemar Sumberg (RA, ERA.4416.2.453).

1944. aastal oli V. Sumberg lühikest aega Otto Tiefi valitsuse sotsiaalminister. Ta vangistati samal aastal, vabanes sunnitöölt 1954. aastal, kuid Eestisse tal naasta ei lubatud ning ta suri Venemaal Novosibirski oblastis Targai puhkekodu pikaajalise juhatajana. 
Eesti Rahva Muuseum avaldas 1921. aastal toonase meditsiinitudengi Voldemar Sumbergi osalusel koostatud "Rahva arstiteaduse korjamise kava" (Sumberg 1921), mille trükkis Eesti Üliõpilaste Seltsi arstiteaduse osakond. Kaheldamatult on küsitluskava antud ajaperioodi üks mitmekülgsemaid. Eessõnas tõdeti, et midagi olulist on määratud hävimisele ning rahvameditsiini teadetest tuleb päästa kõik mis võimalik: "Kokkukogutult pakuks materjal meile kaunikese pildi rahva vaimuteravusest ja materjali läbitöötamisel võidaks kindlaks teha mõndagi tabatud tõtt, millel ka oma tähtsus ei puudu teaduslikkude uurimiste kõrval." Kava oli suunatud ennekõike arstidele ja apteekritele, aga ka kiriku- ja kooliõpetajatele, tudengitele ja kooliõpilastele, soovitusega korjata ennekõike enda lähiümbruskonnast, endalt ja perelt ning vanematelt inimestelt. Soovitati ka märkida andmestiku kontekst - isikute aadressid, kellelt ja kust kuuldud või loetud (kirjanduses - missuguses raamatus, ajakirjas, ajalehes); samuti koguda käsikirju, ajakirju, pilte ja joonistusi arstimiskohtadest ja ravijatest, ja jälgida rahvalikku väljendusviisi, sealhulgas murret. Materjal tuli saata jaokaupa ERMi ja saadetule oodati pidevaid täiendusi. Anti ka võimalus oma kogutu tasu eest ära anda - selleks tuli kogumise korraldajatega ühendust võtta.

Kava ise jagunes kaheks osaks: Esimeses osas olid teemadeks sünnitused; ema eest hoolitsemine pärast sünnitamist; lapse eest hoolitsemine; sünnituste ärahoidmine (abort). Sünnituste all esitati küsimusi rasedusaja, sünnituse käigu ja sünnitusabi ning sünnitusjärgse aja kohta. Samuti on toodud küsimused lapse esmase hoolduse ning raseduse katkestamise ja kuuriiete kohta. Lühikese esimese osa lõpus on lõik "Surma puhul", muuhulgas on küsitluskavas konkreetne küsimus - Kas ja kuidas vähendati surmaeelseid valusid? Küsimused surnukeha hoidmise viiside ja paiga kohta on üldise iseloomuga.

Küsimustiku teise ja suurema osa moodustasid üldised küsimused: haigused; haiguse nimetus; kirjeldused; ärahoidmine; teisele saatmine; arstimisviisid; arstimisaeg; isikute nimed. Esmalt on haiguste all loetletud sisemised, haava-, naha-, naiste-, laste-, silma-, kõrva-, nina-, suu-, kurgu-, hammaste ja vaimuhaigused. Haigusnimetuste all on toodud üle neljakümne erineva rahvaliku määratluse, näiteks lendva, jooksja ja hall, erinevad silmahaigused, nahanähud, murrud ja nikastused, haavad, külmetused, vingumürgitus, hammaste kiristamine, unepuudus jne. Lisaks on soovitud teada saada võimalikult täpseid kirjeldusi haiguste, haigustest hoidumise ja teistele saatmise kohta. Siia on lisatud ka armumaagia. Küsimusi täiendasid mitmed näited. Kõige pikema nimestiku moodustavad arstimisviisid. Küsitud on näiteks nii arstirohtude tegemise kohta (kas taimne või millestki muust tehtud, kodupiirest või apteegist toodud), kui ka seda, mida apteekrid küsimise peale andnud on. Viimasele küsimusele oodati ennekõike vastuseid apteekritelt. Veel paluti kirjeldada arstimisriistu (kõrvakivid, kupusarved jm); saunas ja parsil ning vee, toidu, vaate ja sõnadega arstimist, samuti küsiti maagilisi arstimisreegleid. 
Eraldi lühikesed rubriigid moodustasid arstimisaeg ja isikute nimed (mis aegadel arstiti ning täpsemad isikuandmed ja jutud ravijate kohta). Muuhulgas küsiti, kas ülikoolis õppinuid usaldati rohkem kui "oma" arsti [küsitluskava koostaja jutumärgid]. Samuti on palutud üles kirjutada kõik muu, mida teatakse, kuid mille kohta küsimused puuduvad.

EÜSi-ERMi küsitluskavas rõhutatakse taustaandmete ja konteksti kirjapaneku vajadust. Selle küsitluskava puhul tuleb toonitada, et eraldi on taibatud küsida arvamust koolitatud arsti kohta, mida tavaliselt selleaegsetes küsitluskavades ei esine. Küsitluskavast kumab ratsionaalsuse-irratsionaalsuse temaatika - mida rahvas tegelikult teab inimorganismist ning mida peetakse ravimise ja haiguste juures tõepäraseks.

Voldemar Sumberg ja ka teised võimalikud koostajad on olnud üsna lähedal pärimuslikule materjalile. Küsimuste püstituses ei jää muljet rahvapäraste teadmiste võoristamisest, vähesest tundmisest või eelduspärasest üleolekust. Küsimused on esitatud asjalikult ning nende sisu lähtub silmnähtavalt konkreetsest olemasolevast ja teadaolevast rahvameditsiinilisest pärimusest. Koostaja(te) seisukohtadest torkab silma, et nende hinnangul on kõige asjalikumad rahvameditsiini kogujad arstid ja apteekrid (vrd nõukogude perioodil neile sekundeerivaid Mihkel Kaske ja Kaljo Villakot, vt Tupits 2008 ja 2010).

Küsitluskava vastused jõudsid ERMi ning anti hiljem üle Eesti Rahvaluule Arhiivi (kogu tähistus ERM). Materjal on tekstistatud Eesti Kirjandusmuuseumi folkloristika osakonna poolt; kogutu sisaldab mitmesuguseid loitse, sh on ka lätikeelsed loitsud, mitmesuguseid ravivõtteid katku ja halli, naistehaiguste ja nahahaiguste kohta ning rahvaveterinaariat. On ka kirjeldusi kohalike nõidade kohta. Muuhulgas kogus vastava kava järgi hilisem prominentne arst Siegfried (Siim) Lind (1899-1984).

ERMis on olemas märked 1937. aastast, kokku 14 vastust (KV 32), mis järgivad 1921. aastal koostatud küsitluskava. Lisaks on kaks vastust 1962. aastast, mis järgivad Mihkel Kase ja Kaljo Villako küsitluskava aastast 1959, kuid on komplekteeritud vanema küsitluskavaga ühte.

\section{Rahvameditsiinile lähemale}

Ilmselt EÜSi ja ERMi koostöös saadud, aga ehk ka sanitaar-topograafiliste andmete kogumise kogemustele tuginedes kirjutas Sumberg 1922. aastal idealistliku artikli rahvameditsiini ja arstiteaduse lähendamisest ning rahvameditsiini mõistmise põhimõtetest (1922; artikli käsikiri asub Rahvusarhiivis (RA, ERA.4617.1.26)), kutsudes ühtlasi kõiki üles rahvameditsiini koguma. 
Käsikirja ja artiklit võrreldes võib leida mitmeid erinevusi. Näiteks on autor otsinud parimat sõnastust - algvariandis kasutas ta "meditsini" asemel sõna "arstiteadus", samuti on mustandis kasutatud "ülikooli arstiteadust", mis parandatud "ülikooli meditsiiniks", ning trükivariandis on lõpuks kirjas arstiteadus. Lisaks kasutas Sumberg mõistet "modern arstiteadus". Muuseas märkis Sumberg, et rahval on ükskõik, kas aitab kirik, või jumalad ja usk oma minevikust, heas vahekorras peab olema kõigiga. Usutunne ja tarvidus selle järele on suur, seetõttu ei tohi sellele ülevalt alla vaadata, leidis Sumberg, samas kaotavat rahvameditsiin tihti just usu tõttu mõistuse, nii et administratiivvõimud on sunnitud vahele segama (RA, ERA.4617.1.26: 60). Artikli käsikirjas on Sumberg arutlenud ka psühholoogiliste mõjude üle haiguse tekkes ja ravis, need aga artiklisse sisse ei ole jäänud (samas: 66, 67). Sumberg viitas lisaks tuttavale advokaadiprouale, kelle lapse keegi tark nahahaigusest terveks ravis, samuti ühele tähtsale riigimehele, keda modern arstiteadus pikalt aidata ei suutnud, üks tark aga terveks tegi (samas: 68). Kõik sellised ekstreemsemad viited on lõppvariandist välja jäänud. Sumberg leidis, et rahvameditsiin ei ole muinasteadus, vaid pikalt järeleproovituna konkureerib see modernmeditsiiniga ning võiks ülikooli arstiteadust ainult rikastada (samas: 68). Olemasoleval kujul toovat rahvaarstiteadus aga rohkem kahju kui kasu (samas: 69).

Sumberg rõhutas, et tuleb pääseda inimese hinge ligi, ning külatark, erinevalt arstist, seda oskab. Sellest tuleneb ka tarvidus ülikooli arstiteadusel rahvameditsiini tundma õppida (samas: 73, 74; Sumberg 1922: 47). Samuti on ta leidnud, et selle teadusharu (st rahvameditsiini) korjamine on raskem kui vanavara korjamine (samas: 76 ). Sumberg on nimetanud eestlaste ebausu varasema talletajana Johann Wolfgang Böcklerit, Jakob Hurta ja Ferdinand Johann Wiedemanni, lisaks on käsikirjas mainitud Ilmari Mannineni väitekirja (samas: 77), kuid neid üksikasju artiklis ei ole. Sumbergi eesmärgiks oli rahva- ja akadeemilise meditsiini lähendamine ning ta rõhutas pärimuse tähtsust kultuuris: "Rahva-meditsiin on teatud maanurga kultuurilise tasapinna baromeeter ja sellena on tal etnograafiline ning kultuur-ajalooline tähtsus, mis palju materjali tõotab ka teistele uurijatele mitte arstidele" (samas: 50/75; Sumberg 1922: 45). ${ }^{3}$ Lisaks käis ta välja eesti rahvameditsiinilise sõnastiku loomise idee. Sumberg ei unustanud siiski rõhutada rahvameditsiinis tarvitatavate võtete ohtlikku poolt. Rahvusarhiivi säilikus on ühtlasi separaat Sumbergi artikli trükiversioonist, mille servadele on tõenäoliselt Sumberg ise teinud mitmeid lisamärkusi.

30. märtsil 1922. aastal rajatud Akadeemilise Arstiteaduse Seltsi aastakoosolekul 1923. aastal innustas Sumberg isiklikult arstiteaduse üliõpilasi, et on vaja "rohkem tähelepanu pöörata rahvaliku meditsiini kogumise peale ja jagas välja maal laialilaotamiseks rahva arstiteaduse kogumise kavasid". Akt- 
sioon oli plaanis varemgi, kuid Akadeemilise Arstiteaduse Seltsi tegevusaasta esimesel poolel suvevaheaja tõttu selleni ei jõutud (Bürger 1923: 125-126). ${ }^{4}$ Nimelt oli seltsi põhikirja järgi üheks ülesandeks rahvalike ravitsemisviiside ja vahendite kogumine ning tundmaõppimine. Ühel kevadkoosolekul tegigi Sumberg ettepaneku kasutada kogumiseks suvevaheaega (Talvik 1923: 170).

Rahvameditsiini teemal pidas seltsis 1924 . aasta 6 . veebruaril ettekande ka meditsiinitudeng Hugo Orro, mainides, et tuntakse kolmesuguseid arstimisvahendeid - maagilisi sõnu, ainelist keha (millel puudub arstiv toime) ning moodsale meditsiinile lähedasi vahendeid, "mille nimed seisavad farmakopöas". Lisaks olla Orro maininud terve rea arstihaigusi ja raviaineid ning nimetanud rahvaarste (Sutt 1925: 157).

\section{Eesti Tervishoiu Muuseum ja selle eesmärgid}

Eesti Tervishoiu Muuseum asus aastatel 1924-1928 Tartus, Aia (Vanemuise) tn 46, hiljem (1929-1942) kindral Põdra (Pepleri) tn 32. Vastloodud muuseumil oli 16 osakonda, neist üks pühendatud rahvameditsiinile (Sumberg 1935: 22).

1924. aasta eelarve arutamisel tekkisid Tartu Eesti Arstide Seltsi koosolekul vaidlused ja kahtlused algselt (suurelt) ettevõetud plaanide täideviimises, soovitati alustada tagasihoidlikult ning alustuseks tegeleda tervishoiu vanavara korjamisega. Eelarved võeti vastu siiski esialgsel kujul ning järgnenud V. Sumbergi sõidud asjaajajana välisriikide tervishoiu muuseumidesse kinnitasid, et tervishoiumuuseumid ei pea olema "arstiteadusliku vanavara hoiukohtadeks, vaid alatised tervishoiunäitused ja õppeasutised, kus kõike seda, mis arstiteadusel ja tervishoiul on rahvale öelda, püütakse teha hulkadele kättesaadavaks ja mõistetavaks. Seejuures jääb tervishoiulisele vanavarale ainult niipalju ruumi, kuivõrd see on tarvilik uue mõistmiseks ja hindamiseks ning mispärast ka muuseumi nimetus nende asutiste tööle õieti ei vasta" (Sumberg 1938: 422-423).

Aia (Vanemuise) tänaval oli muuseumi kasutuses $200 \mathrm{~m}^{2}$ pinda ning külastajatele avatud osa koosnes anatoomia, füsioloogia, hambahügieeni, toitumise, nakkushaiguste, ema ja lapse, parasiitide, tiisikuse, tuberkuloosi ja seksuaalhaiguste, kasvajate, kodu-, kooli- ja töötervishoiu, esmaabi, alkoholismi ja rahvameditsiini osakondadest. Viimases olid vaatamiseks väljas ka kupupanemise, aadrilaskmise ning hamba väljatõmbamise vahendid (Ibrus 1927: 99-103).

1928. aastal sai muuseum praeguse Riia ja Pepleri tänava nurgal oma (tänini allesoleva) maja, mis avati 1929. aasta aprillis. Väidetavalt oli tegu ühe eesrindlikuma tervishoiumuuseumiga Baltikumis, millel olid lisaks erinevatele tervishoiuteemalistele osakondadele ja loenguruumile oma laboratooriumid ja töötoad, kus valmistati nt papjeemašeest ja vahast näidiseid ning ka korterid 
direktorile ja teenindavale personalile (Ibrus-Määr 1930: 311-314). Lisaks oli muuseumil raamatukogutuba ning filmi- ja slaidikollektsioon. 1941. aastal määrati muuseum Sanitaarharidusmaja alluvusse ning Sumbergi arreteerimise järel 1944. aastal käis kõik kiiresti alla, 1952. aastaks oli muuseumist järel vaid üks ruum (Markovitš 1995: 7).

Sumberg kirjutas 1925. aastal laiemale avalikkusele muuseumi tööd tutvustades, et lisaks moodsa tervishoiukogu koostamisele kogutakse ka rahvaarstiteadust, "s.t. kõike rahva seas tarvitusel olevaid rohte, arstimisriistu, arstimissõnu ja kombeid, et päästa neid hävinemisest, mis on paratamatu hariduse edasitungimisel" (Sumberg 1925: 19).

Voldemar Sumbergi tasakaalukas hoiak ei olnud siiski omane kõigile. Tema kolleeg Siegfried Lind (kes tudengina oli ise rahvameditsiini korjanud) mainis omakorda, et Eesti Arstide Seltsi arvates on vaja ebaarstimise vastu võidelda, millega peavad tegelema vastavad asutised. Ebaarstide uurimist toimetavatki Eesti Tervishoiu Muuseum. Nn ebaarstidel oli haigete ravimine keelatud ja kriminaalkorras karistatav alates 1934. aastast (Lind 1938: 380, 384). Rahvaarste on ebaarstideks nimetatud mõnedes teisteski Tervise ja Eesti Arsti numbrites. Ka Sumbergi enda toon muutus mõnevõrra aastate jooksul (Tupits 2010: 27).

Tervishoiu Muuseumi dokumentatsiooni ${ }^{5}$ järgi peeti muuseumit "eesti rahva arstiteaduse ja arstimisviiside" igakülgse kogumise ja analüüsi keskuseks, sh peeti vajalikuks koguda ka tervishoiu vastaseid tarbeasju (puudub täpsustus, mida sellega silmas peeti). Sellise teadmistekogumi pealt loodeti pöörata avalikkuse tähelepanu kahjulikele võtetele ja nende vastu võidelda (RA, ERA.4617.1.10: 5, 11, 22, 24). Muuseumis peeti aktiivselt tervishoiuteadlikkust tõstvaid loenguid kogu Eestis ja raadio vahendusel, loodi mitmeid näituseid ja publitseeriti infomaterjale.

Aja jooksul vähenes rahvameditsiini (tähtsuse) mainimine dokumentides ja avaldatud kirjutistes üsnagi märgatavalt. Ilmus üht-teist võrdlevat, nt lisakommentaariks akadeemilisele raviviisile nii Sumbergi kui teiste sulest, samuti mitu kirjutist Mihkel Kaselt (kes 1959. aastal algatas uue rahvameditsiinikogumise koos Kaljo Villakoga) või mainitakse teda kui materjali läbitöötajat. Ei ole võimatu, et läbitöötatud materjali moodustasid just Tervishoiu Muuseumile saabunud kaastööd ning hiljem ehk ka ERAs asuv materjal (asutused asusid ju ligistikku).

Voldemar Sumbergi panus rahvameditsiini kogumisse on olnud märkimisväärne, sest õige mitu aastat tegi ta vastaval teemal üsna tugevat sisepropagandat just meditsiinilistes ringkondades, st kaasas nii kolleege kui ka tudengeid. Muuseumi dokumentatsioonist nähtub, et Sumberg isiklikult pidas avalikke loenguid ka rahvameditsiini teemadel, nt esmaabist rahvameditsiinis (RA, ERA.4617.1.33: 162). 
Säilinud andmetest ei tule välja, kellega võis Sumberg täpsemalt konsulteerida juba tudengina, kui koostati ühiskava Eesti Rahva Muuseumiga. Sumbergi võis nõustada nt Ilmari Manninen ${ }^{6}$, kellest oli 1922. aastaks saanud ERMi direktor ja kes avaldas pärimusalaseid artikleid ka arstidele või keegi teine etnograafidest või folkloristidest. Selleks ajaks olid asutatud nii eesti ja võrdleva rahvaluule õppetool (1919) kui ka etnograafia dotsentuur (1922) Tartu Ülikoolis. Muuseumi dokumentatsioonist ega ka mõningatest e-posti teel tehtud päringutest toonastele partneritest tervishoiumuuseumitele Euroopas ei selgunud, kas Sumberg võis rahvameditsiinikogu ülesseadmisel võtta eeskuju mõnest välismaa tervishoiumuuseumist - Teine maailmasõda tegi mitmel puhul omad korrektiivid ka välismaiste muuseumide ajaloomälu osas.

\section{Rahvameditsiini küsitluskava ja kogumine}

ETMi küsitluskava “Asuge rahva-arstiteaduse korjamisele”, mis 1925. aastal üle Eesti laiali saadeti, on sisult 1921. aasta küsitluse lühendatud variant. Oletatavasti tingis küsitluskava lühiduse selle spetsialiseeritus. Lisaks võidi lähtuda eelmise küsitluskava kogemustest ja osati esitada soovitut konkreetsemalt. Taas võib oletada, et oma osa küsitluskava sisus oli toonastel etnograafidel ja folkloristidel. ETMi allesjäänud materjalide vahel seda kava ei ole, kuid saatuse tahtel on koopia sellest säilinud Eesti Kirjandusmuuseumi Eesti Rahvaluule Arhiivis (ERA) asuvate eesti folkloristika ajaloo materjalide hulgas (EFAM, ERA 18 A, kaust "Kogumine").

Küsitluskava eessõna on koostatud ajakohaselt kultuuri päästmise stiilis, keskendudes rahva teadmistele haiguste arstimisest ja ärahoidmisest, tõe tabamisest mõne rohu äraproovitud mõjul, arstimise kommetest ja toimetustest, arstimise väärviiside kindlakstegemisest. Osutati, et rahvaarstiteaduse korjamisele ei ole seni suurt rõhku pandud ja mõndagi on juba kaduma läinud, sest vanad kombed vähenevad iga päevaga. Seega on vaja teadmisi koguda ja kadumisest päästa.

Erinevalt teistest toonastest küsitluskavadest sisaldab antud versioon küsimusi arstimisel tarvitatavate tehniliste abivahendite kohta. On põnev, et eraldi küsiti teavet ravitsejate bioloogia-alaste teadmiste kohta - "mida teab rahva-arst, tark või nõid inimese kehaehitusest ja tegevusest. Milleks arvatakse näituseks tarvis olevat: 1) maksa, 2) põrna, 3) neerusid, 4) verd, 5) pääaju, 6) südant”. Eelduspäraselt oodati vastuseid, mis selgitaksid analüüsil välja ravitseja tõsiseltvõetavuse ametliku meditsiini seisukohast, teisalt annaksid informatsiooni rahvapärase ettekujutuse kohta organismi ülesehitusest. Antud küsimus seostub tugevalt ratsionaalsuse-irratsionaalsuse otsingutega rahvame- 
ditsiini uurimises laiemalt, ehk siis - mida teavad ravitsejad inimkehast tegelikult. Üldjuhul teistes tolleaegsetes küsitluskavades küsimusi rahva teadmiste kohta inimorganismist ei leia. Veel juhitakse vastajate tähelepanu arstimisel kasutatavate maagiliste toimingute kirjapanekule; õpetatakse, mida ja kuidas korjata: asju ja riistu, raamatuid ja käsikirju, rohutaimi, arstimiskombeid ning sõnu. Korjata soovitatakse ligemas ümbruskonnas, sh iseendalt, küsida teateid rahvaarstidelt või siis nende patsientidelt, kui ravitsejad ei soostu vastama.

Muuseum saatis välja nii küsitluskavasid kui ka rahvaarste puudutavaid kaarte (823 kaarti) arstidele, apteekritele, loomaarstidele, õpetajatele, vallasekretäridele jne. Kaartvastuseid laekus tagasi 589 (71\%). Teada saadi 394 rahvaarsti nimi ja elukoht ning tegevusala, lisaks pandi muuseumile rahvameditsiini koguva korrespondendina kirja 218 isikut (Sumberg 1935: 60-61). Arhiivisäilik pakub rahvaarstide hulgaks siiski 395, neist maakondade kaupa - Harju 19, Järva 6, Lääne 22, Petseri 32, Pärnu 71, Saare 55, Tartu 66, Valga 23, Viljandi 38, Viru 19 ja Võru 44 (RA, ERA.4617.1.26: 82). Üksikutelt säilinud kaartidelt leidub ka koomilis-tõsiseid ülestähendusi rahvaarstide olemasolu kohta, nii on Kaarma kihelkonnast saadetud kaart-vastus, milles tähendatakse, et kuna maakonnalinn Kuressaare kaheksa akadeemilist haridust omava arstiga on lähedal, "puuduvad (välja surnud) mainit. rahwaarstid" (RA, ERA.4617.1.26: 123).

1925. aasta eelarvesse plaaniti kahele stipendiaadile kummalegi 8,000 marka kolme kuu töö eest ning lisati selgituseks: "Rahva-meditsiini kogumiseks. Sellega on juba koos Akadeemilise Arstit. Seltsiga algus tehtud ning üle maa rahva-arstide nimed ja aadressid kogutud. Nüüd on tarvis vastavaisse kohtadesse stipendiaatisid saata. Esialgu 2 stipendiaati 3 suve kuu jooksul" (RA, ERA.4617.1.11: 39p).

1926. aasta aruandest selgub, et: " 2 väljasaadetud stipendiaati kogusid 1 kuu jooksul 5728 rida rahva-meditsiini. Ühtlasi olid stipendiaadid varustatud ülesvõtte-aparaatidega ja pildistasid rahvameditsiini alal teotsevaid "rahva arste", nende elukohti jne. Peale selle on mitmed isikud saatnud väärtuslikke andmeid rahvaarstiteaduse kohta" (RA, ERA.4617.1.130: 122).

Muuseumi eelarved (RA, ERA.4617.1.3: 13, 13p; 16; 21; 22; 24; 27; 28p; 42; $46 \mathrm{p} ; 52 ; 54 ; 86)$ näitavad, millised vahendid olid võimalikud kogumiskulude katmiseks, sh kogujate palk. ${ }^{7}$ Aastatel 1923-1926 oli muuseumi eelarves kogumiseks plaanitud 50000 Eesti marka (500 krooni $\left.{ }^{8}\right){ }^{9}$ aastatel 1927-1929 oli vastav eelarve 40000 marka (400 krooni); 1929.-1930. aastal 300 krooni; 1931.-1932. aastal 500 krooni; 1932.-1933. aastal 200 krooni ja 1933.-1934. aastal 100 krooni. Eelarvete 1931-1934 kommentaaridest nähtub koostöö Akadeemilise Emakeele Seltsiga ${ }^{10}$ rahvameditsiini kogumisel. 1930. aastal pöördus seltsi murdetoimkond rahalise abi saamiseks mitmete institutsioonide, sh ERMi, ERA ja Tervishoiu Muuseumi poole (RA, ERA.R-2362.2.55: 8). Vähemalt 


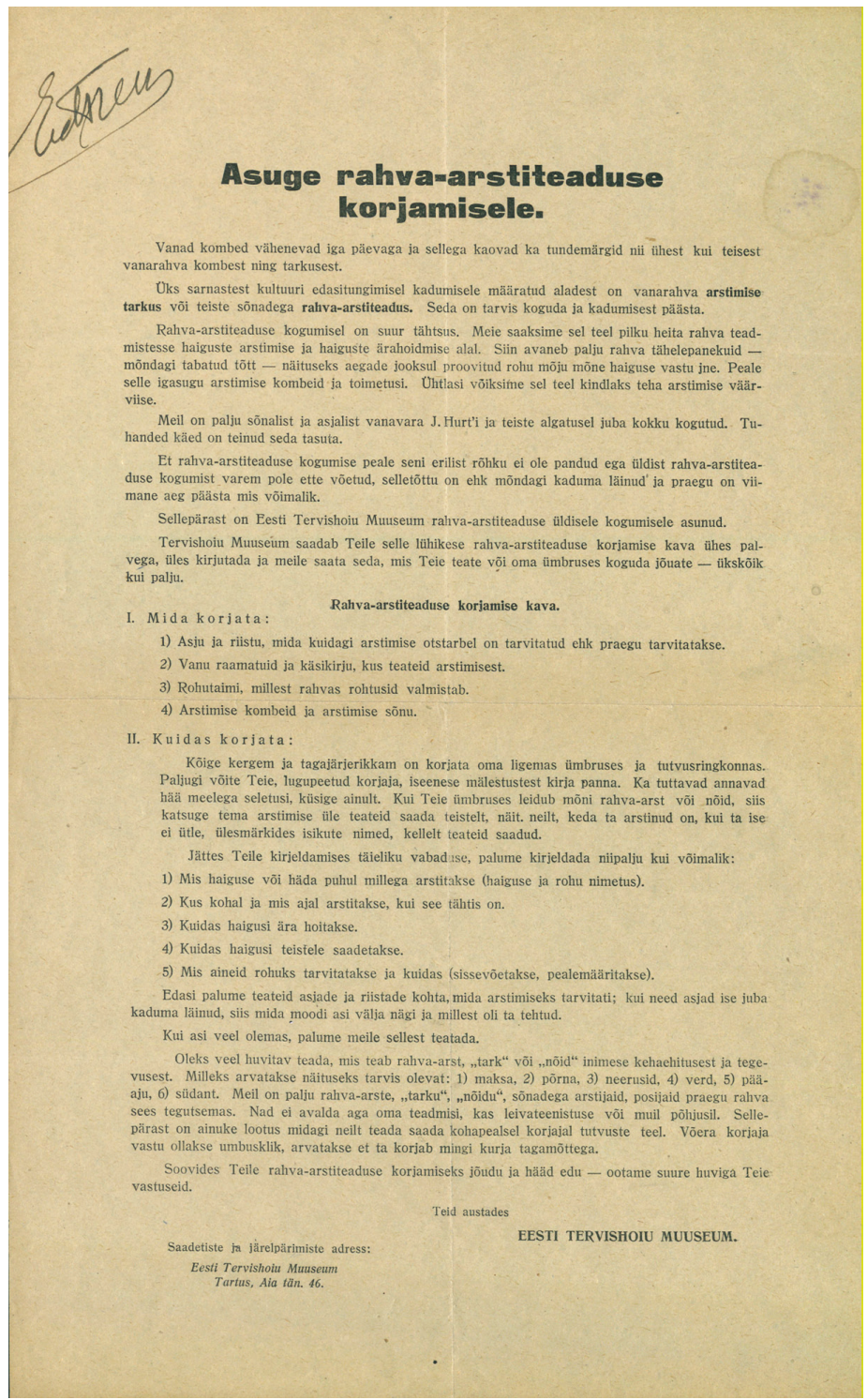

Pilt 2. Eesti Tervishoiu Muuseumi küsitluskava (EFAM, ERA 18 A).

aastatel 1930-1932 jagas murdetoimkond stipendiume tudengitele, kes muu teabe hulgas kogusid ka sõnavara ja murdematerjale tervise, haiguste, surma ja ravisõnade kohta (RA, ERA.R-2362.2.57: 308; 334; 339). Arvatavasti ongi tegemist Tervishoiu Muuseumi eelarvetes mainitud koostööga, ehkki otsene kinnitus sellele puudub. 
Sissetulevate ja väljaminevate kirjade registrite ning muuseumi väljastatud kogumistunnistuste (nt RA, ERA.4617.1.33; RA, ERA.4617.1.31; RA, ERA.4617.1.42; RA, ERA.4617.1.43) põhjal oli võimalik tuvastada kolm tudengit, kes rahvameditsiini kogumas käisid: Voldemar Kiss (1901-1977), Arnold Reiman (1903-1963) ja Karl Kaur (1900-1972). Juunis-juulis 1926 viibis V. Kiss Vana-Vändras ja K. Kaur Räpinas. On selgusetu, kus täpselt oli Arnold Reiman. Vihjete põhjal viibis tema praktikal muuseumis, aga tegi ka kogumistööd 1926. aastal toimuva "Üleilmlise Karskuskongressi" jaoks.

Tudengeid juhendati posti teel ning nad pidid pidama päevikut, saatma oma asukoha aadresse, tööplaane ning kogutud materjale muuseumile (RA, ERA.4617.1.43: 27). Näiteks viitab üks register, et Karl Kaur on 1926. aasta juuni lõpus kirjutanud raskustest rahvameditsiini kogumisel, sest kõik hoidsid temast eemale (RA, ERA.4617.1.2: 63p). Voldemar Kiss oli kogumas ka 1927. aasta suvel (RA, ERA.4617.1.42: 35). Onnekombel on ühe sissetulevate kirjade registri vahel säilinud pagineeritud, kuid köitmata postkaart Karl Kaurilt Arnold Reimanile 1926. aastast.

Räpina 15.VII 26

Arno!

Päevapildistamis aparaadi sain alles 12-al s.k.p. kätte - ootasin teist Petseris ja sellepärast jõudsin hiljem Leevile, kust selle asukoha üle teateid sain. Olen teinud juba mõningad ülesvõtted, kuid peab tähendama, et igaüks just fotografeerimiseks oma nõusolekut ei avalda. Mõni tahab pilti saada j.n.e. - Ei tohi lubada ka, mõtlen ega muuseum ometi hakka neile pilte saatma.

Oma töö lõpetan 16-al juulil s.o. juba homme. Tartusse mõtlen tuleva esmaspäevaks jõuda, kus oma materjali üle annan. - Ei või uhkustada, et seda just väga palju oleks, kuid siiski olen mõndagi saavutanud ja plus kogemused kuidas üldse rahva arsti uurida. Tervitab Kaur (RA, ERA.4617.1.2: 66, 66p).

Ühele masinakirjas aruandele on käsitsi lisatud märkus, et 1925. aastal koguti 3778 rida rahvameditsiini. Teksti ingliskeelne versioon ütleb ilmselt eksituse tõttu samaks koguseks 8778 rida (RA, ERA.4617.1.10: 6, 24). Aruanne aastatest 1926-1927 mainib, et kaks tudengit on kogunud ühe kuu jooksul 5728 rida rahvameditsiini (täpsustamata nii tudengeid kui kogumiskuud). Veel teinegi aruanne kinnitab, et tudengitel oli kaamera rahvaarstide ja nende kodude jm pildistamiseks (RA, ERA.4617.1.130: 122).

Sumbergi 1935. aasta artikli järgi kogusid tudengid 878 rida (vrd eelmise lõiguga). Muu oli kogutud kaastööliste poolt. Kokku oli muuseumil 16563 rida rahvameditsiinilisi teateid (Sumberg 1935: 60-61), jääb aga selgusetuks, mille järgi ridu loeti. 


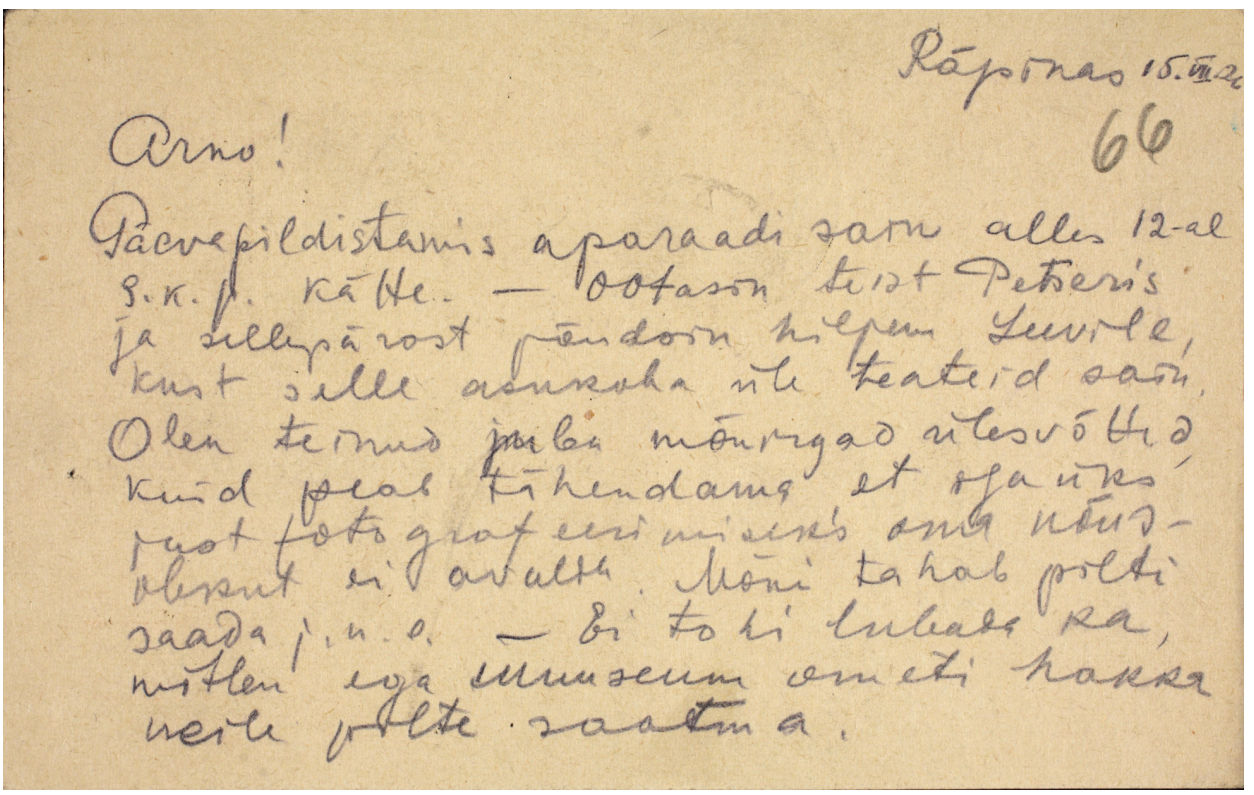

Pilt 3. Postkaart Karl Kaurilt Arnold Reimanile.

\section{Vabatahtlikud kogujad ja rahvameditsiinilised andmed}

1924. aasta küsitluskava vastused laekusid peamiselt 1925. aastal, aga ka järgnevatel aastatel. Saadetised on käesoleva teema seisukohalt kõige olulisemas Rahvusarhiivi säilikus (ERA.4617.1.26, Muuseumile isikute poolt saadetud rahvameditsiini alased käsikirjad. Rahvaarstide nimekiri) kronoloogiliselt segamini köidetud, kohati rühmitatud selgelt saatjapõhiselt, vastustega vaheldumisi on ajaleheväljalõikeid, anonüümseid märkmeid ja käsikiri Tervise artiklist koos mustandiga, samuti nimekiri rahvaarstidest ja neist huvitatutest, kes muuseumile pärimust sooviksid korjata. Vahel on keeruline aru saada, kelle kirja või märkustega on tegu, sest teksti juures puudub nimi või isegi initsiaalid. Oletuslikult on vähemalt osa neist Voldemar Sumbergi märkused/mõtisklused rahvameditsiini teemadel.

Tervishoiu Muuseum ei tegelenud nt pagineerimise või palade nummerdamisega. Viimast on teinud kaastöölised oma materjale kirja pannes, kuid mitte kõik. Küll on märgitud leheserva kirjade muuseumisse saabumise kuupäev.

Kogu teeb põnevaks asjaolu, et säilinud on ka vihik lätikeelse rahvameditsiinilise materjaliga, sisaldades peamiselt loitse, aga ka vanasõnu (RA, 
ERA.4617.1.26: 127-142p). Seejuures kannab vihikuke läti folkloristikas tähendusrikast pealkirja "Trudi N 2", mis nime poolest vihjab Fricis Brīvzemnieksi teosele "Läti rahva etnograafilised materjalid. Etnograafiaosakonna toimetised. 4. raamat" ("Материалы по этнографии латышского племени. Труды этнографического отдела. Книга 4", 1881), kus ta avaldas loetelu läti mõistatusi, vanasõnu, loitse ja rahvaravivõtteid. Teosele on omane nummerdatud palad ja eripärane ortograafia, mille nii sisu kui ka stiili kopeeriti omakorda paljudes lätikeelsetes käsikirjalistes üleskirjutustes. ${ }^{11}$ Antud vihikuke siiski F. Brīvzemnieksi teose koopiate hulka ei kuulu, sest ühtegi kokkulangevust ei õnnestunud tuvastada. Kahjuks puuduvad ka taustandmed vihiku loovutaja või koguja/saatja kohta.

Eraldi säilik on veel Rahvaarstide register koos andmetega eriala ja elukoha kohta (RA, ERA.4617.1.154), mis on puhtand loeteluga rahvaarstidest üle Eesti ning kõige tõenäolisemalt tagasisaadud kaartvastuste ümberkirjutus, mille kokkusurutum versioon on hoiul säilikus RA, ERA.4617.1.26.

Kogujate kohta pakub huvitavaid lisaandmeid sissetulnud kirjade raamat aastatest 1922-1926 (RA, ERA.4617.1.2), kus on teinekord kommentaare kirjade ja kogumisdetailide kohta. Nimeliselt on siin mainitud nt Johan(n) Kool Puiatu alevikust, kes on jaanuaris 1925 avaldanud soovi hakata muuseumi korrespondendiks ning sama aasta juulis teatab nii kindlast soovist rahvaarstiteadust korjata kui ka palub muuseumil kodukandis korraldada loenguid. Korduvalt on muuseumile pakkunud kogumisalast koostööd A. Teder Võrust, küsides kava ja pakkudes kaastööd tervishoiualaste küsimuste lahendamiseks ning abi taimede kollektsiooni loomisega. Oskar Vink on 1925. aastal mitmeid kordi saatnud rahvameditsiinilist materjali Pala-Nõvalt. A. Werendel, M. Madisson, A. Tigason ja H(ans) Martin ${ }^{12}$ on kas pakkunud koostööd, saatnud kogumisplaani või on mainitud, et kirjale tuli muuseumil juurde maksta. Koolidest on sellest ajast üles märgitud Kernu algkool (Harjumaa) ning Kosehelki algkool (Petserimaa). Kaastööliseks on olnud ka dr Sild Avinurmest ning Harald Laumets Kodaverest. Eriti agaralt seisis enda eest E. Grünberg, kelle saadetiste juurde on korduvalt märgitud, et saatja soovib oma saadetise rahalist hindamist ning ühel juhul küsib kaastööline otseselt honorariks 300 marka. Veel julgemalt on teine kaastööline, J. Meimer, oma kirja lõpus küsinud 900 marka töötasu (RA, ERA.4617.1.26: 31).

Lisaks leidub materjali hulgas nimesid, mis on tuttavad folkloristidele - nii on nt Jaan Saalverk Kurna vallast üles antud isikuna, kes võiks olla huvitatud rahvameditsiini kogumisest (RA, ERA.4617.1.26: 125). Üks-ühele võrdlust kõikide saadetud nimede (n-ö võimalike kaastööliste) ja tegelike kaastööliste isikute kokkulangevuse osas ei ole siinkohal siiski tehtud.

Nagu öeldud, ei ole alati võimalik kindlaks teha konkreetse saadetise või märkuste autorit. Õnneks on nii mõnigi kaastöö säilinud koos saatja nime ja 
isegi aadressiga, kokku üle mitmekümne nime. Ei ole võimatu, et nii mõnegi nimetu üleskirjutuse autor on eelmainitud tudeng. Näiteks nimestik Setumaa rahvaravitsejate nimede, ravimisampluaa, elukoha ja muude märkmetega võib pärineda Karl Kaurilt, Kosehelki algkoolilt või kelleltki teiselt. Ühes ülevaateartiklis loetleb Sumberg üles 17 nime ja Kernu algkooli kui kaastöölised, neist ridaderohkemad olid E. Grünberg (2225), A. Vindi (1150), H. Mägi (2900) (1935: 61).

Allesjäänud vastuste hulgas on õnnekombel ka üks rahvapatoloogiat puudutav vastus M. Madissonilt: "Südant arvati kõige tegevuse juhiks (nagu peaaju)" (RA, ERA.4617.1.26: 3p). Mitmes saadetises kirjeldatakse, mida ja kuidas erinevate taimedega ravida, millised on erinevad hambaravi, nahahaiguste, peavalu, roosi jt haiguste ravivõtted ning leidub ka rahvaveterinaariat ja loitse. Mõningate kirjade alguses on saatjad osutanud, et "vanal ajal" arstiti inimesi teismoodi kui "nüüd" või et tegu on "enne muiste" arstimise abinõudega. Selge on, et ETMis leidis erilist tähelepanu taimravi (tõenäoliselt kui kõige ratsionaalsem osa rahvameditsiinist), sest tekstides on taimenimed ja -saadused punaselt alla joonitud. Samas on teinekord pliiatsiga alla joonitud ka nt vistrike või hambaravi.

Tekstinäited (originaalesitus ja ortograafia on säilitatud):

1. Kui pä̈̈ga kusagile vastu jooksed siis tuleb kolm korda nuaga risti vajudada kuhu kohast on haiged saanud, siis ei tõuse muhku pähe.

2. Kui loom haigeks järsku jääb tuleb kolm korda püssiga looma kõhu alt läbi lasta. (RA, ERA.4617.1.26: 5)

$* * *$

Üks kõige tähtsamatest rohtudest oli üheksawägew. Teda keedeti teeks ning tarwitati 9 haiguse wastu. Mõned inimeste rohtudest on üheksawägewa teedest: Närwi haiguse ja langetõbe wastu. Peale selle tarwitati teda ka mõne looma haiguse wastu. Ka tehakse üheksawägewa wanni, kuid ma ei tea, mis otstarbeks. (RA, ERA.4617.1.26: 6)

***

Tahetakse soola tü̈̈gast ära kaotada, siis otsitakse üks surnud loomakont ja wajutatakse sellega kolm korda soolatü̈̈ka peale, siis juba, kui on wajutatud pannakse kont jälle just niisama moodi maha, kui enne oli. Seda tehakse kolm neljapäewa õhtut järgi mööda, kondi juurest ära tulles ei tohi tagasi waadata, siis ei pidawat terweks saama. (A. Liiv. RA, ERA.4617.1.26: 9) 
Kui söögi tahtmist ei ole. Wõedakse kerisse tahma sisse see annab söögi isu. Kui inimene alles lolliks on jäänud, siis andakse inimesel sisse mutti werd. (Elwine Piksarw. RA, ERA.4617.1.26: 12p)

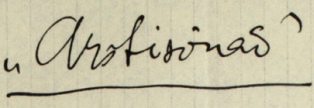

11 Jummal ssand meile jäa meid ara pane hukca sa. Koigest patust vabas tii ning anna ondsat tuxka. kuradist meid paimenda, Sulle annan enda ka Ristirahwas kinnituse zoña. Aamen aamen, feesu nimel aamen. fusms kristus meile jair, Pîha vaim sa meile jaia, Fagane ära saadan. thina vanna sine fummalase esa" fummalase poja puha waimm nimel a amen. Soron meti jalge alla kange fessa nimel aamen. Haile olga, meile tulga appi temma nimmel tristare vere vigus just ning välläst port. hine vallá sa rojiane paha maim ssand feesus kistus, sa oled colm micst Steahjust päastra, Sanieli livi avvast ja Sotti Soodumast. ssand, feesus custus, páastá esi sedá elajä ehx inimese vaiva. Aamen. II Liisu vivike Puhiast.

Sumur. Tepeler aroh inime all, Maioni va Dabri ia whtudege pole vorode. Ha masscerija.

Pilt 4. Arstisõnad Liisu Tuvikeselt (RA, ERA.4617.1.26: 83). 
Ehkki koguti palju andmeid rahvaarstide nimede, spetsialiseerumisvaldkondade ja elukohtade kohta ning mõningail juhtudel on olemas ka andmete allikad, on allesjäänud materjalid valdavalt põhjalikuma taustata - kellelt, millal ja kuidas täpsemalt koguti. Nii on ETMi rahvameditsiinikogu suures osas tänasele uurijale kontekstitu.

Vahel on siiski kirjas värvikaid muljeid kogujate püüdluste ja raskuste kohta, nagu kirjeldab Oskar Vink Pala-Nõvalt, kelle saadetud materjali on säilikus kõige rohkem:

Sain sõbralt korjanduslehe, ja mõtlesin: oot, oot, ma teen proovi, vast õnnestub mul midagi vanarahva arstimistarkusest teada saada.

Hääkene küll, astub ühel vihmasel päeval "vanatark” uksest sisse. Teen juttu, küsin ühtteist, pööran viimaks jutulõnga “arstimissõnade” pääle. Mees kuulab jutu ära, ütleb korra "ahah" ja pistab ruttu juurde: "Vihm on juba üle läinud" ning katsub, et ruttu minema saab.

Niisugune on "vanatarkade" usaldus eestiteaduse kogumise kohta. [---] (RA, ERA.4617.1.26: 16, 16p)

Muuhulgas on O. Vink tänuväärselt üles kirjutanud ravimisvõtete teisendeid, seejuures sama haiguse kohta mitmetes saadetistes ning küsis muuseumilt nõu taimede korjamise, käsitlemise ning saatmise osas.

1. Sammaspoole vastu: Kasetohu pääle tehti viiskand; [joonis viiskannast] sellega vajutati üheksa korda sammaspoole pääle ja visati siis põlevasse ahju. Siis pidi sammaspool ära kaduma.

Teisend: Alustassi ehk taldriku pääle pandi trehtli moodi paberist toru ja pisteti teravast otsast põlema. Tassile koguva pruuni vedelikuga määrides pidi sammaspool ära kaduma (RA, ERA.4617.1.26: 16p, 17)

$* * *$

Palun teatage mulle, kuidas tuleb taimi saata, (korjandusleht on mul kaduma läinud) kas kuivatatult? kuidas tuleb kuivatada? kõige juurtega? lehtedega? õitega? Kas tuleb ka vastav seletus juurde lisada? (millal õitseb? kui kaua? j.n.e)? (RA, ERA.4617.1.26: 19p)

Viimasele on halvastiloetavalt punase pliiatsi ning Sumbergi allkirjaga juurde kirjutatud, et on vaja teatada ja saata taimede korjamise juhend. Sumberg on ilmselt teinud endale eraldi väljakirjutusi Oskar Vingi saadetud materjalist, nagu osutab üks peamiselt pliiatsikirjas märkusteleht. Eraldi on alla joonitud ja hüüumärkidega tähistatud lause, et iga tõsise haiguse puhul lastakse verd (RA, ERA.4617.1.26: 37), kuid jäetud lisamata jätkulause: "See sünnib saunas, 
vana kuu lõpul” (RA, ERA.4617.1.26: 86p). Ühtlasi puudusid originaalis hüüumärgid ning konkreetselt oli tegu üleskirjutusega Setumaalt.

Mõned ülestähendused on selgelt Voldemar Sumbergi enda omad, sest neil on all initsiaalid:

Tiisukuse (kopsuhaigete) arstimine peedi vedelikuga - soojalt juua keedetud peetide vett.

Pärnumaal, Tammiste vallas, Jantson, Suure-Kõrtsi talu. Tark asuda Pärnu linnas kes sellega arstib tõbe.

Kase "tuulepesa" keeta ja selle veega last pesta kui lapsel "piimahaigus"mis tulla ema piimast, kui see liig rammus. Väikesed punased vistrikud. Jäärjas, Pärnumaal.

Paul Johansoni andmetel.

1926a - oktoobril. V.S. (RA, ERA.4617.1.26: 23)

Lisaks käsikirjalistele teadetele saadeti muuseumisse tõepoolest ka esemeid nt hambatangid, aadrirauad, kupusarved. Nii võib sissetulnud kirjade raamatust leida märke, et Harald Laumetsa isaisa Jaan Laumets Kodaverest on lasknud sepal teha hambatangid, millega "tõmbas palju hambaid, puu klopi üle kangutades", samuti saatis Laumets muuseumile ühed aadrirauad, mida tema isaisa on tarvitanud (RA, ERA.4617.1.2 ${ }^{13}$ ).

Sumberg on kirjutanud, et muuseumile lähetasid esemeid neli inimest, loetledes üles õde Vilperi, õpilase Haugmetsa, Joh(annes) Meimeri ja E. Eisenschmidti (Sumberg 1935: 61). Arhiiviallikatest oli nimeliselt võimalik tuvastada ainult Harald Laumetsa saadetised - ei ole võimatu, et Haugmets ja Laumets on tegelikult üks ja sama isik, sest nende asukohaks on märgitud kas Alatskivi või Kodavere, kust saadeti muuseumile sepa valmistatud hambatangid. Jääb siiski ebaselgeks, kui palju rahvameditsiinilisi arstimisvahendeid muuseumi kogus tegelikult oli.

Esemekogu olemasolu ja selle väljapanekut tõestab kunagi Tervises ilmunud foto rahvameditsiinilistest abivahenditest (Eller 1928: 196). Pildil kujutatakse püsinäituse osana aadrilaskmise ja kupupanemise riistu.

Samas on mõni kaastööline märkinud, et omab raviks tarvitatavaid esemeid:

Mull on olemas wanu arsti asju Wana kirjadega hõbe sõrmus ja kõrwa kiwi. Ka olen 3 pae (mäerahkjad) muretsenud. Kui elu on, siis tulewal suwel saadan mõned maa taimed mis arstimiseks pruugiti. Kõige austusega A. Werendel. (ERA.4617.1.26: 35) 


\section{Ärge laske verd.}

\section{Dr. M. Eller, Kastre-Võnnu}

Väga tähtis on, et organismis oma loomulik verehulk säiliks. Inimesed patustavad sagedasti sel!e nỏude vastu: - on kellelgi selja-, pea- j. n. e. valud, siis pööratakse iseäranis maal, kôige pealt „külatarkade“ poole; lastakse tihti kogu selg ja kael „kuppe" täis, et „halb veri välja jookseks". Enamasti tarvitatakse seda arstimisviisi vanemate inimeste juures, kes juba isegi väheverelised ning sellega veel nõrgemaks jäävad. Iseäranis kardetav on "aadrilaskmine": tehtud haavake võib juhtuda mõnele suuremale arteerile ning inimene sellega mõne minuti jooksul verest tühjaks joosta ja surra. Pealegi on vanemate inimeste veresoonte seinad enam-vähem lubjastunud, ja verejooks ei taha

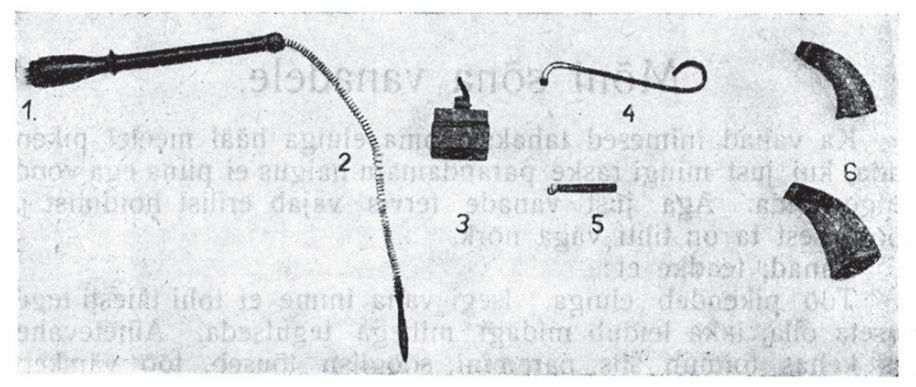

Tervishoiu Muuseumi kogudest.

Verelaskmise riistad ja kupusarved.

1. Palju nõelu, mis vedrust 2 tõmmates torusse kaovad. Toru ots asetatakse nahale ja lastakse nüüd vedru lahti, mistõttu nõelad nahasse palju auke löövad

3. Kupumasin, mis vedru abil korraga palju haavu lööb.

4. Aadri raud traadist.

5. Väike puupeaga verelaskmise nuga.

6. Kupusarved. Harilikult oina või looma sarv, mille otsa seotud tükike sea põit, millesse väike auk tehtud, et verd imedes suhu ei tulcks. On nahasse ühel eelnimetatud viisil haavad löödud, pannakse sarv haavale ja imetakse verd. Kui põiesae auku ei tehta, sits tehakse sarvesse pisut tuld ja pannakse haavale. Sarv jääb siis naha külge kinni ja imeb ise end verd täis.

kuidagi enam peatuda. Verelaskmise riistad on "külatarkadel " keetmata ja puhastamata, nende nurkadel võib pesitseda kardetavaid pisikuid, kes verre sattudes veremürgistust ja surma võivad esile kutsuda.

Seadusandlus vaatab sarnasele väärarstimisele väga pehmelt. Enamasti võetakse siis külatarkadel riistad käest, kuid ",arstid“

Pilt 5. Rahvapärased ravimisriistad väljapanekuna (Eller 1928: 196). 
Selge on, et Rahvusarhiivi ERA.4167 fondis ei ole enam neid 16000 rida, millest on kirjutanud Sumberg (1935), ühtki ülesvõtet rahvaarstidest ega rahvapäraste raviesemete kogu. Muuseumi esemetekogu tassiti laiali, sulatati, müüdi, raamatuid võeti ilmselt ka isiklikuks kasutamiseks. ${ }^{14}$ Fotosid ei ole ka Riigiarhiivis; ${ }^{15}$ Eesti Filmiarhiivis on küll olemas Eesti Tervishoiu Muuseumi fotokogu (EFA.193, sisaldab 43 säilikut), kuid see kujutab Tallinna diakonissihaiglat ja erinevate samariitlaste esmaabikursuseid. Ka Tartu Ülikooli raamatukogus säilitatava Sumbergi kaasaegse, doktor Herbert Normanni isikuarhiivi järgi leidub Normanni fotokogus fotosid Tervishoiu Muuseumist (TÜR, F 77, mis sisaldab kirjavahetust, aga ka muud ja TÜR, F 78 "Eesti Tervishoiumuuseumi album ja album fotodega välisriikide tervishoiumuuseumidest”), milles olevad fotod ei ava siinkohal vajalikku tausta. Edasi ei aidanud ka Viktor Kalnini isikuarhiiv (TÜR, F 149). Eesti Rahva Muuseumisse midagi Tervishoiu Muuseumi kogudest (nt fotod või arstimisriistad) teadaolevalt ei jõudnud ning Rahvusarhiivi infosüsteemi teabe kohaselt anti säilinud herbaarkogu 1980. aastate lõpul tänasele Eesti Tervishoiu Muuseumile (vt kommentaar nr 5).

\section{Kokkuvõtteks}

Eesti Tervishoiu Muuseumi rahvameditsiini kogumist iseloomustades võib tõdeda, et peamiselt rõhutati andmete ja teadmiste päästmise vajadust, rahvaarstide paikkonna ja tegevuse kaardistamist. Arstide seisukohast oli vajalik ka "vaenlast" tundma õppida ning osutada materjalide näitel väärarusaamadele tervishoius ja koduses ravis. Kuna meditsiinitudengid ning ETM tegid koostööd ERMi ja miks mitte ka ERAga, ei erine kogumisstrateegiad omavahel siiski kuigivõrd. Peamine erinevus on siinjuures meedikute vaatevinkel, mis püüdis otseselt avastada meditsiinilist tõde ja valet rahvapärases ravimises. Etnograafid-folkloristid lähtusid peamiselt frontaalsest andmete üleskirjutamisest. Samas võib V. Sumbergi näitel öelda, et ka meedikute seas leidus neid, kes püüdsid rahvaravi mõista, kahte maailma omavahel lähendada ja vähem vastandada.

ETM eesotsas dr Voldemar Sumbergiga tegi tänuväärset tööd nii rahvameditsiiniliste andmete ja raviks kasutatavate esemete kogumisel, rahvameditsiinist kirjutamisel kui ka laiemalt tervishoiualaste teadmiste levitamisel. Arvestades, et rahvaarstide positsioon oli eelmise sajandi kahe maailmasõja vahel jätkuvalt tugev ning rahvapärane ravimine laialt levinud, oli rahvameditsiinialase andmestiku tervishoiumuuseumi kogusse lisamine loomulik samm.

Säilinud dokumentatsioonist pole selge, kuivõrd leidis kogutud materjal kasutamist muuseumi näitustel. Vähemalt olid esitletud ravimiseks tarvita- 
tavad esemed, oletatavasti ka herbaarkogu näited ja ehk mõni originaaltekst kaastöölistelt. Küllap tekitas see osa muuseumi väljapanekutest vastukaja ka toonastes muuseumikülastajates.

Praeguseks on Rahvusarhiivis säilitatavast ETMi kogust alles hinnanguliselt 2000 käsikirjalist rida (lähtudes muuseumi enda loetlemissüsteemist), mille hulka võib siinkohal lugeda nii otseselt haigusi ja nende ravi puudutava info kui ka rahvameditsiini käsitlevad märkmed ning andmed rahvaarstide kohta koos elukohtade ja tegevusalaga. Lisaks on säilinud ajalehtede väljalõiked rahvameditsiini kasutamist puudutavate uudisnupukestega, Sumbergi käsikirjalised märkused jm.

Võib julgelt oletada, et ülejäänud vastused, tudengite päevikud, fotod ja muu hävisid Teises maailmasõjas või veidi hiljem. Teisalt on vähene allesjäänu meeldivalt mitmekesine ning pakub kinnitust nii toonaste uskumuste ja ravivõtete kohta kui ka täiendust teistele rahvameditsiini puudutavatele teadetele erinevates folkloorikogudes.

\section{Kommentaarid}

1 Artikli valmimist on toetanud Haridus- ja Teadusministeeriumi uurimisprojekt IUT 22-4 "Folkloor kultuurilise kommunikatsiooni protsessis: ideoloogiad ja kogukonnad" ja Euroopa Liit Euroopa Regionaalarengu Fondi kaudu (Eesti-uuringute Tippkeskus - CEES).

2 Viide V. Sumbergile kui küsitluskava koostajale põhineb www.utlib.ee andmetel, mis omakorda tuginevad Richard Antiku "Eesti raamatute üldnimestiku 1918-1923" andmetele. Küsitluskaval koostaja nimi puudub.

3 Seda rõhutas Sumberg ka 1923. aastal seltsi ühel koosolekul: "Muinasusuga lähedalt seotud rahvameditsiin toob praegusel kujul rahvale enam kahju, kui kasu. Ei puudu tas aga ka teadusliku väärtusega element, mis modern-arstiteadust rikastada võiks. Rahvameditsiin ei ole tähtis mitte üksi arstiteaduslisest seisukohast, vaid ka etnograafilisest ja kultuur-ajaloolisest, ning sellepärast peab teda hoolega korjama" (Sutt 1925: 157).

4 Samas on mainitud ka Aleksander Rammuli juhatusel 1922. aasta suvel toimunud tervishoiuteemalisi uurimisi maapiirkondades, mida korraldas Tervishoiu Instituut aastatel 1922-1930, kogudes sanitaartopograafilisi andmeid 11 Eesti maakonna kohta. Uurimiste eesmärk oli selgitada, mil määral sõltuvad haigestumus ja suremus ning üldine terviseseisund eluviisist, kommetest, olmetingimustest, toitumisoludest ning muust (TIA).

5 Fond ERA.4617, 1924-1942. Eesti Tervishoiu Muuseumi arhivaalid võeti Riigiarhiivi vastu 1974. aastal Ajalooarhiivist. 1989. aastal korraldati fond ümber. Üks säilik eraldati hävitamiseks ja üks säilik - herbaarium - anti üle Tervishoiumuuseumile. 156 säilikut inventeeriti kronoloogilis-nominaalse tunnuse põhjal ühte nimistusse. Ringkirjad, juhendid, ettekanded, kavad, fotod, eelarved, aruanded, ülevaated, kirjavahetus, nimekirjad, ankeedid, arve ja registratuurraamatud, isikkoosseisu materjalid (ais.ra.ee). 
${ }^{6}$ Eesti Arsti 1924. aasta numbrites kirjutas Ilmari Manninen sündimisest ja lapsepõlvest eesti rahvapärimuses (Manninen 1924).

7 Märkus võib olla seotud välitööl olevate tudengitega. Teisalt maksti nõudmisel ka vabatahtlikele kaastöölistele.

8100 Eesti marka = 1 Eesti kroon. Rahareform margalt kroonile toimus 1928. aastal.

9 Avalikes aruannetes märgiti rahvameditsiini tegelikeks kogumiskuludeks 1924. aastal 9000 marka ning 1925. aastal 19930 marka (Talvik \& Valdes 1926: 153; 1926: 231).

${ }^{10}$ Akadeemiline Emakeele Selts loodi Tartu Ülikooli juurde 1920. aastal.

${ }^{11}$ Fricis Brīvzemnieks (Brīvzemnieks-Treilands, 1846-1907) oli Läti poeet, tõlk, õpetaja ning Läti folkloristika üks rajajatest 19. sajandi lõpus. Lähemalt vt Lielbārdis 2017.

12 Paraku ei olnud võimalik tuvastada kõigi saatjate eesnimesid.

13 Sissekanded nr 846 ja 847.

${ }^{14}$ Eesti Tervishoiumuuseumi peavarahoidja Riina Aderi e-kiri autorile 3.02.2010.

${ }^{15}$ Rahvusarhiivi uurimissaalide talituse juhataja Liina Maadla e-kiri autorile 3.02.2010.

\section{Lühendid}

EFAM, ERA = Eesti folkloristika ajaloo materjalid Eesti Kirjandusmuuseumi Eesti Rahvaluule Arhiivis

ERM = Eesti Rahva Muuseumi rahvaluulekogu Eesti Kirjandusmuuseumi Eesti Rahvaluule Arhiivis

KV = korrespondentide vastused Eesti Rahva Muuseumis

RA = Rahvusarhiiv

TÜR - Tartu Ülikooli Raamatukogu

\section{Viidatud arhiiviallikad}

\section{Eesti Kirjandusmuuseumi Eesti Rahvaluule Arhiiv}

EFAM, ERA 18 A - Asuge rahva-arstiteaduse korjamisele.

\section{Eesti Rahva Muuseum}

KV 32 = Korrespondentide vastused nr 32, Eesti Rahva Muuseum. 


\section{Rahvusarhiiv}

EAA.2100.2.1153 - Sumberg, Voldemar.

ERA.R-2362.2.55 - Murdetoimkonna koosolekute protokollid. 17.10.1933-23.01.1937.

ERA.R-2362.2.57 - Materjalid murdekogujaile küsitlemiseks 1929-1938.

ERA.4617.1.2 - Saabunud kirjade register. 22.09.1922-31.07.1926.

ERA.4617.1.3 - 1923, 1924, 1927, 1929.-1941. a eelarved koos lisadega.

ERA.4617.1.10 - Ringkirjad, juhendid, kavad, fotod, ettekannete ja artiklite käsikirjad muuseumi tegevuse korraldamise ja tervishoiualaste teadmiste populariseerimise kohta. Rändnäituste eelarve. 1924.

ERA.4617.1.11 - Eesti Tervishoiumuusemi ringkirjad ja 1925. a. eelarve. Väljunud kirjade ärakirjad muusemi tegevuse korraldamise, teaduslike tööde avaldamise, loengute pidamise ja filmide näitamise kohta. 19.12.1924-30.12.1925.

ERA.4617.1.26 - Muuseumile isikute poolt saadetud rahvameditsiini alased käskkirjad. Rahvaarstide nimekiri. 05.07.1925-17.12.1925.

ERA.4617.1.31 - Väljunud kirjade register. 28.05.1925-06.12.1926.

ERA.4617.1.33 - Eesti Tervishoiumuuseumi ringkirjad, Väljunud kirjade ärakirjad tervishoiualase tegevuse, propaganda, näituste korraldamise, filmide ja diapositiivide muretsemise kohta. 14.01.1926-29.12.1926.

ERA.4617.1.42 - Saabunud kirjade register. 01.08.1926-28.11.1929.

ERA.4617.1.43 - Väljunud kirjade register. 02.11.1926-07.04.1929.

ERA.4617.1.130 - Muuseumi 1923., 1926/27. ja 1935/36.-1939/40. a tegevuse aruanded koos lisadega.

ERA.4617.1.154 - Rahvaarstide register koos andmetega eriala ja elukoha kohta.

\section{Tartu Ülikooli Raamatukogu}

TÜR, F 149 -Viktor Kalnini isikuarhiiv.

TÜR, F 77; F 78 - Herbert Normanni isikuarhiiv.

\section{Kirjandus}

Antik, Richard 1931. Eesti raamatute üldnimestik 1918-1923. Tartu: Eesti Kirjanduse Seltsi Kirjastus.

Brīvzemnieks, Fricis 1881. Materialy po etnografii latyshskogo plemeni. Trudy etnograficheskogo otdela. Kniga 4. [Läti rahva etnograafilised materjalid. Etnograafiaosakonna toimetised. 4. raamat.] Moskva: Tipografiia S. P. Arkhipova i Ko.

Bürger, Gerda 1923. Akadeemilise arstiteaduse seltsi tegevusest tema esimesel aastal 1922/23. Tervis 10/11. Tartu: Postimees, lk 124-126. 
Eller, Mihkel 1928. Ärge laske verd. Tervis 12. Tartu: Postimees, lk 196-197.

Goršič, Ave 2016. Honouring and Losing Knowledge: Folk Medicine Collection of the Estonian Museum of Hygiene in the Early 20th Century. Stradiňš, Jānis \& Salaks, Juris (toim). Acta Medico-Historica Rigensia Vol X (XXIX). Rīga: Rīgas Stradiṇa universitāte, lk 301-322 (doi: 10.25143/amhr.2016.X.18).

Ibrus, Aleksandra 1927. Eesti Tervishoiu Muuseum. Eesti Arst 3, lk 99-103.

Ibrus-Määr, Aleksandra 1930. Tervishoiu Muuseum uutes ruumides. Eesti Arst 8, lk 311-314.

Lind, Siegfried 1938. 1920.-1934. a. peetud Eesti Arstidepäevade ja -kongresside resolutsioonide ja sooviavalduste teostamisest. Eesti organiseeritud arstkond 1912-1937. Tartu: Postimees, lk 353-384.

Lielbārdis, Aigars 2017. Fricis Brīvzemnieks at the Very Origins of Latvian Folkloristics: An Example of Research on Charm Traditions. Bula, Dace \& Laime, Sandis (toim). Mapping the History of Folklore Studies: Centers, Borderlands and Shared Spaces. Newcastle upon Tyne: Cambridge Scholars Publishing, lk 193-206.

Manninen, Ilmari 1924. Sündimine ja lapsepõlv eesti rahva traditsioonis. Eesti Arst $4,5-6,7-8$.

Markovitš, Lea 1995. Dr. Voldemar Sumberg ja Eesti Tervishoiu Muuseum. Dr. Voldemar Sumberg ja Eesti Tervishoiu Muuseum. Meditsiiniajaloopäevade ettekandeid. Tallinn: Eesti Tervishoiu Muuseum, lk 3-9.

Sumberg, Voldemar 1921. Rahva arstiteaduse korjamise kava. Eesti Rahva Muuseumi väljaanne 17. "Eesti Üliõpilaste Seltsi” arstiteaduse osakonna toimetus. Tartu: J. Mällo trükk.

Sumberg, Voldemar 1922. Rahwa-meditsiin ja arstiteadus. Tervis 6. Tartu: Postimees, lk 41-47.

Sumberg, Voldemar 1925. Eesti Tervishoiu Muuseumi ülesanded rahva tervishoiu alal. Tervis 1-2. Tartu: Postimees, lk 18-20.

Sumberg, Voldemar 1935. Eesti Tervishoiu Muuseum 1924-1934. 10 a. tegevuse ülevaade. Eesti Tervishoiu Muuseumi väljaanne 85. Tartu: [Eesti Tervishoiu Muuseum].

Sumberg, Voldemar 1938. Eesti Tervishoiu Muuseumi saamisloost ja arenemisest. Eesti organiseeritud arstkond 1912-1937. Tartu: Postimees, lk 418-428.

Sutt, Erika 1925. Akadeemilise Arstiteaduse Seltsi koosolekud. Eesti Arst 5. Tartu: Eesti Arstideseltside Liit, lk 156-158.

Talvik, Siegfried jt (toim) 1923. Akadeemilise arstiteaduse seltsi koosolekute protokollidest. Eesti Arst 5/6.Tartu: Eesti Arstiseltside Liit, lk 170-173.

Talvik, Siegfried \& Valdes, Albert (toim) 1925. Arstiliste organisatsioonide tegevus. Eesti Arst 5. Tartu: Eesti Arstiseltside Liit, lk 150-156.

Talvik, Siegfried \& Valdes, Albert (toim) 1926. Arstiliste Organisatsioonide tegevus. Eesti Tervishoiu Muuseumi kassa-aruanne 1925. a. ja eelarve 1926. a. Eesti Arst 6. Tartu: Eesti Arstideseltside Liit, lk 230-232. 
TIA = Tervishoiu instituudi ajalugu. Tartu Ülikool, peremeditsiini ja rahvatervishoiu instituut (kodulehekülg, https://tervis.ut.ee/et/instituudist/tervishoiu-instituudiajalugu-0 - 11. oktoober 2018).

Tupits, Ave 2008. Data Collecting and Research of Folk Medicine in Estonia During the Soviet Era. Journal of Ethnology and Folkloristics 2 (2). Tartu: Estonian Literary Museum, Estonian National Museum, University of Tartu, lk 69-82 (https://www.jef. ee/index.php/journal/article/view/31 - 17. oktoober 2018).

Tupits, Ave 2010. MD Voldemar Sumberg and the Folk Medicine Collection of the Estonian Museum of Hygiene from the 1920s and 1930s. Journal of Ethnology and Folkloristics 4 (2). Tartu: Estonian Literary Museum, Estonian National Museum, University of Tartu, lk 19-30 (https://www.jef.ee/index.php/journal/article/viewFile/53/ pdf_51-17. oktoober 2018).

\title{
Summary
}

\section{Voldemar Sumberg and the folk medicine collection of the Estonian Museum of Hygiene}

\author{
Ave Goršič \\ Researcher, Estonian Folklore Archives, Estonian Literary Museum \\ avegorsic@folklore.ee
}

Keywords: collecting, Estonian Museum of Hygiene, folk medicine, medical history, questionnaire, Voldemar Sumberg

The Estonian Museum of Hygiene (predecessor to the current one) was established in 1922. One of its principles was to collect and analyse knowledge of folk medicine to inform the public about incorrect treatment and to enhance proper, advanced medical knowledge. The museum's contributors were voluntary private persons as well as schools and medical students. The exact number of contributors is not clear. By 1935 around 16,000 lines of folk medicine data had been collected, and various folk medicine equipment was displayed as part of the permanent exhibition. The article introduces physician Voldemar Sumberg's efforts as a student in 1921 (together with other medical students), and as the museum's director in 1924-1925 in collecting folk medicine information, and gives an overview of the remains of the collection that are currently preserved at the National Archives of Estonia.

The museum stressed the need to save folk knowledge and data and to map the locations and activities of folk healers. The physicians tried to learn about the 'enemy' to point out the false treatment used among people. The 1921 and possibly also the 1924 collecting campaigns were conducted in collaboration with the Estonian National Museum, and probably also the Estonian Folklore Archives was consulted; the collecting strategies for folk medicine data did not differ much. The main difference lies in the attitude of the physicians to detect true and false in folk treatment, while the ethnographers-folklorists proceeded from the point of view of a 'complete collection', 
thus trying to collect every piece of information possible without adopting a disparaging attitude. V. Sumberg proved that medical professionals also tried to understand folk medicine, and to bring both folk and medical medicine close together without creating superfluous opposition. Considering the still strong position of folk healers in Estonia between the two world wars, it made perfect sense to gather such data to be preserved in the collections of the Museum of Hygiene.

The remaining documentation of the museum, which began to wane at the end and after the Second World War, does not clarify the extent to which folk medicine material, either manuscripts or healing devices, were on display at the exhibition. It is certain though that some of the medical tools were on display. It is not ungrounded to argue that this section of the exhibition drew response from the visitors.

Today, there are approximately 2000 lines left of all the materials concerning the folk medicine collection in the funds of the National Archives preserving files on the Museum of Hygiene. This involves both direct folk medicine data with names of collectors, notes without clear authorship, and data of folk healers' names, places of residence, and fields of activity. Additionally, there are corresponding newspaper clippings, offprints of newspaper articles, handwritten notes by Sumberg, etc. The article also presents examples of folk treatment.

The rest of the materials, field diaries of medical students hired by the museum, photographs, etc., were destroyed at the end of the Second World War or later. On the other hand, what is left of the collection is very versatile and offers both confirmation and addition to other such data in different folklore collections. 